\title{
Phraseological Units Used in the Functional Styles in English and Albanian Language
}

\author{
Ma. Lediana Beshaj \\ Lecturer at Tirana University Albania \\ beshajlediana@hotmail.com
}

\section{Doi:10.5901/mjss.2013.v4n2p453}

\section{Abstract}

Phraseological phrases are present everywhere and we see a fast growing role of phraseology in a wide range of linguistic disciplines. Scholarly attention has been focused on the semantic and syntactic properties of phraseological units, on various approaches, pragmatic function and cultural peculiarities. However this paper focuses on the stylistic properties of phraseological units and the textual environment and if we do really find phraseological units in different types of genre. Phraseological units are used by the speaker or writer who intends a particular stylistic effect and they are used in accordance to certain genres which are considered as different functional styles. By comparing, contrasting and providing examples of phraseological units in different kind of functional style we aim to have a clear picture and actually see that they are present not only in colloquial level of discourse but they also stretch from fiction to non-fiction. The stylistic potential of the phraseological units is enormous. "Since phraseological units may be relevant stylistic devices, they are strong evidence of a level inside the stylistic system which has been termed 'phraseo-stylistic' (Glaser 1986b) and which combines the systemic and communicative aspects of linguo-stylistic analysis.

Key words: phraseological units, functional styles, fiction, non- fiction

\section{Style and phraseologic units}

Style in discourse is a very complicated issue.Style is very important in relation to the phraseology, it is crucial in analyzing phraseological units in different types of discourse, as well as defining the role that phraseological units play in meaning construction according to the genre of the text. A context oriented approach means that the changes do not occur in isolation, but only as an integral part of the discourse. Depending on the form of communication, almost all the authors make the diference between the verbal and the written discourse, and at the same time they make the connection between the verbal and the written discourse.However the writer's intention is to attrack and retain the reader's attention using a variety of stylistic devices. In the established relationship between the interlocutors in a specific discourse situation, we see the functional styles which recently in the stylistic terminology are respectively named by John Catford in his book "A linguistic theory of translation"

1. Scientific prose style;

2. Official and administration documentation style;

3. Journalistic and publicistic style;

4. Literary artistic style;

5. Religious style;

The standard language, as the highest form that edits and perfects the means of agreement and linguistics expressions, is used in all the fields of human activity, but every field selects, edits, and uses these means according to its own requests. The system of the linguistic means, chosen and selected in accordance to the requirements of a specific area of the human activity, comprises the functional system. In other words the functional stye is the form that the standard takes to fullfil the linguistic needs in a certain field of human activity. Phraseological units as diverse elements in a language are present in all stylistic functional styles. To be aware of the style it is important to know, understand and appreciate the language that we use including fictional and non-fictional literary contexts. By focusing on the language use and on the stylistic elements, scholars have tried to combine linguists approach with literary critics approach in a special interpretation considering both, the functional form and the poetical one (Jacobson 1960). 
The standard language exists and acts in the functional style form. The creation and the development of the functional styles is closely related to the evolution of the standard language itself. In todays standard Albanian language the main functional styles are established with their general characteristics. The functional styles are especially distinguished by the communication sphere and the linguistic functions. We should consider as a main criterion the distinguished linguistic function which "from the stylistic point of view is a form of adopting to the discourse structuring for different types of activities and it is the realization of the language functions in a sphere"1

In the Albanian language, there are considered as two axes, two main language crireria, the norm as a vertical axe and prevalent functions as a horizontal axe. This division brings to a thorough and comprehensive stylistic system of the Albanian language

The functional styles in Albanian language are:

1. Literary and artistic activity style;

2. Political and social activity style;

3. Scientific-technical style;

4. Administrative and state activities style;

5. Religious activity style;

\section{a) Literary and artistic style}

It is the language of literary works. It is important to chose the right linguistic means, the genre the theme, the period in which the story is set, the characters, the author's viewpoint and linguistic capacity etc. The stylistic potential of phraseological units is richer and more versatile in literary and everyday genre. "The language of literary works is distinguished by the use of selected words, which are "vibrant" and "sound beautifully", words and phraseological phrases which express the writer's attitude and feelings"2. To artistically reflect life and the world that sorrounds us, a literary author has recourse to the whole wealth of the national standard language with its expressive means on different stylistic level. As an example, I have chosen a book from the well known writer, not only in Albania, but also in the world, especially in France "Ismail Kadare". The book is titled "Kronike ne gur". On page 240 Harrova fare që ishim të zemëruar me njëri-tjetrin. Ai doli hundë e buzë. Hundë e buzë is an adjectival phraseological unit constructed by two nouns, the meaning of which is sad, upset according to the phraseological dictionary of Jani Thomai. Of course the author has chosen this phrase to have a special connotation and to be closer to his readers as this phrase is too much used in everyday language and conversation. In English in Nicolas Sparks novel "The notebook" on page 1 we read "My life? It isn't easy to explain. It has not been the rip-roaring spectacular I fancied it would be, but neither have I burrowed around with the gophers. The meaning of the idiom rip-roaring according to the Oxford Learner's Dictionary of English idioms is 'wildly noisy'

In fiction we distinguish two main divisions: that of the prose and poetry. In their lexicon there are differences: Poetry lexicon includes the word of the folk poetry of the recent and the previous generation. According to the theme that the writer decides to write about we find words which belong to different fields of life. So in a lengthy narrative, poetry, or in a poem for a technical achievement about someone or an historical event etc. we will find phrases or phraseological units. The words are chosen carefully. Let us see some lines from the great Albanian writer Dritëro Agolli in the poem "Thinking"

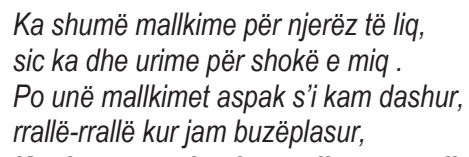

In prose it is difficult to find a literary work without the use of the phraseolgical units which are considered a wealth for this genre. In prose fiction we see that every field of life is depicted and there we find a wide lexicon. Due to its spread and due to the lack of the organization according to a single norm, there are some authors that they do not consider the fiction language as a simple functional style, but as a set of different discourse style. However the author's works should

1Jani Thomai "Leksikologjia e Gjuhes Shqipe"

${ }^{2}$ Xhevat Loshi "Njohuri për stilistikën e gjuhës shqipe",f.14 
follow the rules of the standard and the characteristics of the characters 'discourse should adopt to the stylistics needs. In general the lexicon of the fiction works is distinguished for its double function: the word can have its literal meaning and figurative meaning. On the whole, the use of stylistic devices depends on the individual author's intention and personal taste and thus cannot be added to the linguistic features of a particular genre or subgenre.

Political and social style

It is the language of the political and social activities, of journalism, propaganda, reports, speeches, political discussions and of different articles related to this field. In this style we find a selected lexicon, wide range of terminology, mostly words which have a literal meaning. In this style we see even phraseological units which are used appropriately in different situation and different events. The writer chooses to use an idiom to penetrate to the reader, so that, what they want to get across would be acquired properly. In the "Shqip" newspaper of the 12 March 2013 we read an article and the headline was:

Dikur qe banka e tretë më e madhe në Itali, por disa drejtues të saj, të joshur nga bonuset e mëdha, morën përsipër rreziqe të tepërta dhe filluan të manipulojnë bilancet për të fshehur humbjet. Tashmë, disa gjenden në burg, ndërsa fati i bankës dhe i qytetit të Sienës janë në pikëpyetje të madhe.

Pikpëyetje e madhe - big question according to the dictionary of Jani Thomai means doubious and the other is moren persiper rreziqe- undertake obstackles. The author here choses to use these phraseological units in order to have a stronger connotation.

In the daily mail of the 13.March.13 we read:

Tory MEP Martin Callanan, leader of the European Conservatives, accused the Parliament of 'flying in the face of public opinion' by dismissing calls for belt-tightening and even pressing for new EU tax-raising powers to fund spending. 'The European Parliament is engaging in the worst kind of posturing, which makes it look completely out of touch with reality,' he said. 'The EU budget deal was a reasonable compromise between many competing demands. 'Mr Callanan urged Mr Cameron and other EU leaders to 'stand firm' behind the budget figures agreed last month.

\section{b) Scientific and technical style}

In this genre we have the language of scientific works, studies, articles and the language of technical and scientific activities etc. A general characteristic of science fiction is the wealth and the abundance with words and phrases of different fields of wisdom. However we can immediately notice this genre by the use of the words which are specific respectively in the field of science. The use of phraseological units is limited, though we have phraseological units which derive from various fields of science and are incorporated into the everyday language and belong to the genres we mentioned so far. In English we have bells and whistles - which means all the elements of a new product. This idiom originates from the everyday language used by ordinary people, now it is used in science when they launch a new product. We will now see how the scientific term, used in science has come to use in everyday language i.e. rocket science which means that something is very easy. In Albanian we would have e shumëzoj me zero - se vrerësoj dikë ose dicka, ia shkeli gazit - iku me shpejtësi , i ka humbur pasuordi - kur dikush është i hutuar, etj .

\section{c) Judicial and administrative style}

In this style different official documents are compiled like the judicial decisions, constitution, laws, acts, bills, etc. The lexicon of this style is limited and the words are used in their literal meaning, phraseological units are used less and there is a tendency to use foreign words especially international ones. We find collocations and preposition and conjunction composites, and some collocation of the bookish style which being used so often and continuously, have become like formulae considered typical elements of the language.Some phraseological uits are translated word by word and they are considered carbon "calque" phraseological units. They do not carry any expressive connotation, that's why they are used in this style( break the ice take part,considering that . as a result, according to the law, on behalf of ,as above etc. An example would be from the civil code of the Albanian Republic article 583 Hipoteka shuhet : a) me shuarjen e detyrimit b) me humbjen e sendit të lënë në hipotekë.c) me heqjen dorë te kreditorit. Heq dorë means to give up. In English for 
instance there are such words like in bad faith which means dishonest, without sincerity; burden of proof, minister without portofoloio, persona non grata

d) Religious style

In this style we find religious works and the use of phraseological units is present especially in the ancient writings which belong to different religions and different cultural traditions p.sh. Oh, ye of little faith Fig. You who trust no one. (Jocular; the word ye is an old form of you used in the Bible.) You thought I wouldn't show up on time? Oh, ye of little faith. Or to cut the Gordian knot - 'to deal with a difficult problem in a strong, simple and effective way' (from the legend saying that Gordius, king of Gordium, tied an intricate knot and prophesied that whoever untied it would become the ruler of Asia. It was cut through with a sword by Alexander the Great). In Albanian, an example is arka e Noes- When you search for a safe heaven.

The core of the development of every style is the use of means from the language treasure, in accordance to the requirement of every field. Therefore, the careful and responsible work of the scientists, journalists, writers, teachers, and whoever speaks and writes a certain language contributes into the development of these styles. These different styles or genres do not show a division or give priority to one or the other, on the contrary they perfect, enlarge, and increase the language values in various society activities. In every genre and style we should exploit the stylistic norm ,the linguistic norm as a whole ,and use as much as possible the linguistic means in general, otherwise the style would be anemic, dry, and without inside force. ${ }^{3}$

Studying the styles, stylistic means, in our case the use of phraseological units have a pragmatic importance, as they help everyone who writes to preserve the peculiarities of the style to which his writing belongs to.

\section{References}

Catford.J "Investigating English style

Lloshi,Xh "Vështrim stilistik për mjete shprehëse në gjuhën shqipe", Gjuha jonë, 1981

Lloshi.Xh "Stilistika dhe Pragmatika

Ristani,V "Kontribut në studimet përkthimore gjatë viteve '90", Tiranë 2010

Stefanllari, " "Fjalor frazeologjik Anglisht Shqip", Tiranë 1998

Thomai,J "Leksikologjia e gjuhës shqipe", Tiranë 2006

Thomai,J “ Fjalorë frazeologjik I gjuhës shqipe", Tiranë 2010

Oxford "Learner's dictionary of English idioms" 1994

Examples taken from

Agolli .D "Poezi"

Daily mail http://www.dailymail.co.uk

Gazeta shqip

Kadare.I "Kronikë në gurë"

Sparks.N "The notebook"

${ }^{3}$ Thomai.J Leksikologjia e Gjuhës Shqipe 2006. 